\title{
Front Matter: Volume 7244
}

, "Front Matter: Volume 7244," Proc. SPIE 7244, Real-Time Image and Video Processing 2009, 724401 (10 February 2009); doi: 10.1117/12.824890

SPIE Event: IS\&T/SPIE Electronic Imaging, 2009, San Jose, California, United SPIE. States 


\title{
PROCEEDINGS \\ IS\&T/SPIE \\ Electronic \\ maging \\ Science and Technology
}

\section{Real-Time Image and Video Processing 2009}

\author{
Nasser Kehtarnavaz \\ Matthias F. Carlsohn \\ Editors
}

19-20 January 2009

San Jose, California, USA

Sponsored and Published by

IS\&T-The Society for Imaging Science and Technology

SPIE 
The papers included in this volume were part of the technical conference cited on the cover and title page. Papers were selected and subject to review by the editors and conference program committee. Some conference presentations may not be available for publication. The papers published in these proceedings reflect the work and thoughts of the authors and are published herein as submitted. The publishers are not responsible for the validity of the information or for any outcomes resulting from reliance thereon.

Please use the following format to cite material from this book:

Author(s), "Title of Paper," in Real-Time Image and Video Processing 2009, edited by Nasser Kehtarnavaz, Matthias F. Carlsohn, Proceedings of SPIE-IS\&T Electronic Imaging, SPIE Vol. 7244, Article CID Number (2009).

ISSN 0277-786X

ISBN 9780819474940

Copublished by

SPIE

P.O. Box 10, Bellingham, Washington 98227-0010 USA

Telephone +1 3606763290 (Pacific Time) · Fax +1 3606471445

SPIE.org

and

IS\&T-The Society for Imaging Science and Technology

7003 Kilworth Lane, Springfield, Virginia, 22151 USA

Telephone +1 7036429090 (Eastern Time) · Fax +1 7036429094

imaging.org

Copyright (C) 2009, Society of Photo-Optical Instrumentation Engineers and The Society for Imaging Science and Technology.

Copying of material in this book for internal or personal use, or for the internal or personal use of specific clients, beyond the fair use provisions granted by the U.S. Copyright Law is authorized by the publishers subject to payment of copying fees. The Transactional Reporting Service base fee for this volume is $\$ 18.00$ per article (or portion thereof), which should be paid directly to the Copyright Clearance Center (CCC), 222 Rosewood Drive, Danvers, MA 01923. Payment may also be made electronically through CCC Online at copyright.com. Other copying for republication, resale, advertising or promotion, or any form of systematic or multiple reproduction of any material in this book is prohibited except with permission in writing from the publisher. The CCC fee code is 0277-786X/09/\$18.00.

Printed in the United States of America.

Paper Numbering: Proceedings of SPIE follow an e-First publication model, with papers published first online and then in print and on CD-ROM. Papers are published as they are submitted and meet publication criteria. A unique, consistent, permanent citation identifier (CID) number is assigned to each article at the time of the first publication. Utilization of CIDs allows articles to be fully citable as soon they are published online, and connects the same identifier to all online, print, and electronic versions of the publication. SPIE uses a six-digit CID article numbering system in which:

- The first four digits correspond to the SPIE volume number.

- The last two digits indicate publication order within the volume using a Base 36 numbering system employing both numerals and letters. These two-number sets start with 00, 01, 02, 03, 04, 05, 06, 07 , $08,09,0 A, O B \ldots 0 Z$, followed by 10-1Z, 20-2Z, etc.

The CID number appears on each page of the manuscript. The complete citation is used on the first page, and an abbreviated version on subsequent pages. Numbers in the index correspond to the last two digits of the six-digit CID number. 


\section{Contents}

vii Conference Committee

\section{SESSION 1 REAL-TIME HARDWARE}

724402 Iris matching with configurable hardware (Invited Paper) [7244-01]

R. N. Rakvic, R. P. Broussard, U.S. Naval Academy (United States); D. Etter, Southern Methodist Univ. (United States); L. Kennell, J. Matey, U.S. Naval Academy (United States)

724403 Image segmentation based upon topological operators: real-time implementation case study [7244-02]

R. Mahmoudi, M. Akil, Unité Mixte UMLV-ESIEE, CNRS, Univ. Paris-Est (France)

724404 Real-time embedded atmospheric compensation for long-range imaging using the average bispectrum speckle method [7244-03]

P. F. Curt, M. R. Bodnar, F. E. Ortiz, EM Photonics (United States); C. J. Carrano, Lawrence Livermore National Lab. (United States); E. J. Kelmelis, EM Photonics (United States)

724405 Grayscale image segmentation for real-time traffic sign recognition: the hardware point of view [7244-04]

T. P. Cao, G. Deng, D. Elton, La Trobe Univ. (Australia)

724406 A comparison between DSP and FPGA platforms for real-time imaging applications [7244-05]

M. Shirvaikar, T. Bushnaq, The Univ. of Texas at Tyler (United States)

724407 Hardware architecture to accelerate the belief propagation algorithm for a Wyner-Ziv decoder [7244-06]

T. Horvath, D. He, IBM Thomas J. Watson Research Ctr. (United States)

\section{SESSION 2 REAL-TIME CAMERA SYSTEMS}

724408 Real-time implementation of single-shot passive auto focus on DM350 digital camera processor [7244-07]

M. Gamadia, N. Kehtarnavaz, The Univ. of Texas at Dallas (United States)

724409 Real-time development system for image processing engines [7244-08]

S. Goma, R. Gheorghe, M. Aleksic, Advanced Micro Devices, Inc. (Canada)

7244 OA Bayer bilateral denoising on TriMedia3270 [7244-09]

H. Phelippeau, ESIEE, CNRS, Univ. Paris-Est (France) and NXP Semiconductors (France);

M. Akil, ESIEE, CNRS, Univ. Paris-Est (France); B. Dias Rodrigues, Univ. Federal de Minas Gerais

(Brazil); H. Talbot, ESIEE, CNRS, Univ. Paris-Est (France); S. Bara, NXP Semiconductors (France) 
7244 OB Real-time global motion estimation for video stabilization [7244-10]

T. Tajbakhsh, Silicon Image, Inc. (Germany)

\section{SESSION $3 \quad$ REAL-TIME VIDEO PROCESSING}

7244 OC Selective application of sub-pixel motion estimation and Hadamard transform in H.264/AVC [7244-11]

A. Abdelazim, M. Yang, C. Grecos, D. Ait-Boudaoud, Univ. of Central Lancashire (United Kingdom)

7244 OD Real-time detection and tracking of multiple objects with partial decoding in H.264/AVC bitstream domain [7244-12]

W. You, Information and Communications Univ. (Korea, Republic of) and Univ. of Augsburg (Germany); M. S. H. Sabirin, M. Kim, Information and Communications Univ. (Korea, Republic of)

7244 OE Adaptive interpolation filter method for improving coding efficiency in H.264/AVC [7244-13] K. S. Yoon, H. W. Cho, Pusan National Univ. (Korea, Republic of)

7244 OF Video calibration for spatial-temporal registration with gain and offset adjustments [7244-14] C. Lee, J. Lee, G. Seo, Yonsei Univ. (Korea, Republic of)

7244 OG Real-time visual tracking system modelling in MPSOC using plafform based design [7244-15] Z. J. Jia, T. Bautista, A. Núñez, C. Guerra, M. Hernández, Univ. de Las Palmas de Gran Canaria (Spain)

\section{SESSION 4 REAL-TIME ALGORITHMS}

$7244 \mathrm{OH} \quad$ Real-time vehicle detection and tracking based on perspective and non-perspective space cooperation [7244-16]

J. Arróspide, L. Salgado, M. Nieto, F. Jaureguizar, Univ. Politécnica de Madrid (Spain)

7244 Ol Real-time vision-based traffic flow measurements and incident detection [7244-17] B. Fishbain, Tel-Aviv Univ. (Israel) and Univ. of California, Berkeley (United States); I. Ideses, Tel-Aviv Univ. (Israel); D. Mahalel, Technion - Israel Institute of Technology (Israel); L. Yaroslavsky, Tel-Aviv Univ. (Israel)

7244 OJ Real-time depth map manipulation for 3D visualization [7244-18] I. Ideses, Tel-Aviv Univ. (Israel); B. Fishbain, Univ. of California, Berkeley (United States); L. Yaroslavsky, Tel-Aviv Univ. (Israel)

7244 OK Accelerating sub-pixel marker segmentation using GPU [7244-19] H. Handel, Univ. of Heidelberg (Germany)

$7244 \mathrm{OL} \quad$ Fuzzy set and directional image processing techniques for impulsive noise reduction employing DSP [7244-20]

V. Ponomaryov, A. Rosales-Silva, F. Gallegos-Funes, National Polytechnic Institute of Mexico (Mexico) 
7244 OM Correction of artifacts in correlated double-sampled CCD video resulting from insufficient bandwidth [7244-21]

R. H. Philbrick, Ball Aerospace \& Technologies Corp. (United States)

7244 ON Unsupervised exposure correction for video [7244-22]

X. Petrova, S. Sedunov, A. Ignatov, Samsung Research Ctr. (Russia)

724400 Determination of vehicle speed in traffic video [7244-23]

M. Mehrubeoglu, Texas A\&M Univ.-Corpus Christi (United States); L. McLauchlan, Texas A\&M Univ.-Kingsville (United States)

7244 OP Variable disparity-motion estimation based fast three-view video coding [7244-24] K. Bae, Samsung Thales Co., Ltd. (Korea, Republic of); S.-C. Kim, Y. S. Hwang, E. Kim, Kwangwoon Univ. (Korea, Republic of)

Author Index 
Downloaded From: https://www.spiedigitallibrary.org/conference-proceedings-of-spie on 26 Apr 2023

Terms of Use: https://www.spiedigitallibrary.org/terms-of-use 


\title{
Conference Committee
}

\author{
Symposium Chair \\ Nitin Sampat, Rochester Institute of Technology (United States) \\ Symposium Cochair \\ Jan P. Allebach, Purdue University (United States) \\ Conference Chairs
}

Nasser Kehtarnavaz, The University of Texas at Dallas (United States)

Matthias F. Carlsohn, Computer Vision \& Image Communication (Germany)

Program Committee

Mohamed Akil, École Supérieure d'Ingénieurs en Électronique et Électrotechnique (France)

Chang Y. Choo, San José State University (United States)

Reiner Creutzburg, Fachhochschule Brandenburg (Germany)

Philip P. Dang, STMicroelectronics (United States)

Sergio R. Goma, ATI Technologies Inc. (Canada)

Christos Grecos, University of Central Lancashire (United Kingdom)

Rastislav Lukac, University of Toronto (Canada)

Antonio Núñez Ordóñez, Universidad de Las Palmas de Gran Canaria (Spain)

Volodymyr I. Ponomaryov, Instituto Politécnico Nacional (Mexico)

Fatih M. Porikli, Mitsubishi Electric Research Laboratories (United States)

Luis L. Salgado, Universidad Politécnica de Madrid (Spain)

Mukul V. Shirvaikar, The University of Texas at Tyler (United States)

Stephan Stilkerich, EADS Astrium GmbH (Germany)

Shan Suthaharan, The University of North Carolina System (United States)

Leonid P. Yaroslavsky, Tel-Aviv University (Israel)

\section{Session Chairs}

1 Real-Time Hardware

Nasser Kehtarnavaz, The University of Texas at Dallas (United States)

2 Real-Time Camera Systems

Mukul V. Shirvaikar, The University of Texas at Tyler (United States) 
3 Real-Time Video Processing

Mehrube Mehrubeoglu, Texas A\&M University-Corpus Christi (United States)

4 Real-Time Algorithms

Christos Grecos, University of Central Lancashire (United Kingdom) 